\title{
Smoking behaviour and attitudes towards smoking of medical students in Australia, Japan, USA, Russia, and Estonia
}

Jean-François Tessier, Paul Fréour, Chakib Nejiari, Dominique Belougne, John W Crofton

\begin{abstract}
Objective-To assess the behaviour, knowledge and attitudes of medical students towards smoking, and to stimulate interest in the problem among students and their teachers.

Design - As part of a global survey, firstand final-year students from eight centres in five industrialized countries (Australia, Japan, USA, Russia and Estonia [formerly part of the USSR]) replied anonymously to a structured questionnaire in their own teaching language.

Subjects - A total of 1280 replies was analysed. Participation was $94 \%$ for firstyear students, $82 \%$ for final year. The percentage of females overall was $44 \%$ but varied widely, from $12 \%$ in Tohoku, Japan, to $78 \%$ in Moscow.
\end{abstract}

Results - The prevalence of daily smoking in male medical students varied from nil in the USA to $48 \%$ in St Petersburg; in females from nil in Japan to $14 \%$ in St Petersburg. Many smokers had already made serious attempts to quit; many, except in Japan, expected to have succeeded within 5 years. Most considered smoking harmful to health (with lower rates in smokers), but, even in the USA and Australia, there was important ignorance about tobacco as a major cause of certain conditions, notably cardiovascular disease, laryngeal and bladder cancer, and neonatal mortality, with some differences between countries; in Japan and the former USSR the figures were low (53\% and $51 \%$, respectively) even for lung cancer. High proportions in Australia and the USA, but much lower proportions in Japan and Estonia, would give routine advice on quitting to smoking patients, but in all countries most lacked confidence in their counselling skills. Australian and US students were most, and Japanese students least, conscious of their exemplar roles. There were similar trends between countries in support of preventive legislation. There was widespread ignorance of the preventive effect of tobacco taxation.

Conclusions - Trends in smoking behaviour, and to some extent in knowledge and attitudes, reflected the history of the anti-smoking campaigns in these countries. US and Australian students had lower smoking rates than those in Japan and the former USSR. The former were more conscious of their exemplar role and more ready to counsel patients on quitting (though lacking confidence in their skill to do so); they were more aware of, and supportive of, preventive measures. There were similar trends between countries in knowledge of smoking-related diseases, but important gaps in knowledge remained even in Australian and US students. In all the countries the great majority of students lacked confidence in their counselling skills and most were ignorant of the value of taxation as a preventive measure. These results provide an important challenge to medical education in Japan, Russia and Estonia; some significant deficiencies also need to be remedied in Australia and the USA.

(Tobacco Control 1993; 2: 24-29)

\section{Introduction}

The Tobacco and Health Committee of the International Union against Tuberculosis and Lung Diseases initiated in 1985 an international study on the behaviour, knowledge and attitudes of first- and final-year medical students regarding tobacco smoking. The aims of the study were (1) to obtain baseline data against which future changes could be measured; (2) to examine attitudes towards, and knowledge of, smoking as a public health problem; (3) to stimulate interest in the problem among these future doctors and their teachers; and (4) to improve medical education in this field.

We have already published the results of the pilot survey, ${ }^{1}$ and subsequent results for 14 European countries, ${ }^{2} \mathrm{Asia}^{3}$ and Africa and the Middle East. ${ }^{4}$ Each participating country will receive its own results for local publication. In this report we present results from four industrialised, but quite diverse, countries in different continents: Australia, Japan, USA and what was, at the time of the survey, the USSR - now Russia and Estonia. In consequence there is little point in reporting average figures for all the centres. Comparisons between countries are more meaningful and of greater interest. 
Material and methods

There were eight participating centres in what are now five countries: Sydney in Australia; Tohuku and Hiroshima in Japan; St Petersburg and Moscow in Russia; Tartu in Estonia; Denver, Colorado, and San Francisco, California in the USA. As elsewhere in the global survey, centres were selected as being reasonably representative of their country through direct contact with a national colleague or colleagues known to one or more of the authors. For the USA, the data from Denver are for first-year students only and from San Francisco for final-year students only; these have been combined in the tables as a "USA centre." The other centres and countries provided data from both years. In a number of the tables the results from Russia and Estonia are combined as "USSR."

The questionnaire used was based on one designed for health professionals jointly by the World Health Organisation (WHO), ${ }^{5}$ the International Union against Cancer, and the American Cancer Society. For a detailed outline of the questionnaire see our report in this journal of the African and Middle Eastern section of the survey. ${ }^{4}$ The questionnaires and the protocol detailing the procedures, were sent to a local coordinator in each country. In Japan and (former) USSR the coordinator arranged for translation into the local teaching language. The translations were checked for accuracy by an appropriate linguist in France. The coordinator then arranged for students to complete the questionnaires anonymously at a single session, usually in a classroom. $\mathrm{He} /$ she was asked to ensure that there was no pressure on students as to the nature of their responses. The questionnaires were subsequently analysed by the Laboratoire d'Informatique et de Bio-Statistique, University of Bordeaux, France.

Participation was high : a mean of $94 \%$ for first-year students and $82 \%$ for final year. Although we do not have details of the reasons for absence, the high participation rate indicates that the results were likely to be representative of student knowledge and attitudes. Some students failed to provide usable answers to some questions, so the totals are not necessarily identical for all sections. To avoid undue bias by large numbers in an individual centre, where the number of students substantially exceeded 200 , a random sample of 200 questionnaires was analysed. The chi- square test of significance was used for comparisons, either between two categories or for trends among categories.

In analysing smoking behaviour, "exsmokers" were defined as those who formerly smoked but no longer did so. "Neversmokers" is self-explanatory. Smokers were divided into those who smoked occasionally and those who smoked daily. In analysing the replies on attitudes and knowledge, daily and occasional smokers have been grouped together as "smokers."

\section{Results}

DEMOGRAPHIC DATA

The total number of students included in this study from the five countries (table 1) was 643 in the first year, and 637 in the final year $(1280$ in total), of which $56 \%$ were male and $44 \%$ female). There was considerable variation from country to country and even within countries, with percentages of female students varying from $12 \%$ in Tohuku to $78 \%$ in Moscow.

\section{PERSONAL SMOKING BEHAVIOUR}

Prevalence of smoking

Table 2 gives the figures for both years combined by sex and centre. Prevalence of daily smoking differed greatly among countries, with relatively high male rates in Japan and the former USSR, very low rates in Australia, and nil in the USA. Female rates were nil in Japan and the USA, very low in Australia, and less than a third of the substantial male rates in the former USSR. In the relatively small US sample there were only two smokers, both "occasional" and both female.

Table 1 Demographic data (first and final years combined) by gender and country

\begin{tabular}{lccc}
\hline & \multicolumn{2}{c}{ Sex $(\%)$} & \\
\cline { 2 - 3 } & Male & Female & $\begin{array}{c}\text { Total } \\
\text { students }\end{array}$ \\
\hline AUSTRALIA & 65 & 35 & 193 \\
JAPAN & & & \\
$\quad$ Hiroshima & 85 & 15 & 219 \\
Tohoku & 88 & 12 & 193 \\
USA & 59 & 41 & 75 \\
Ex-USSR & & & \\
St. Petersburg (Russia) & 44 & 56 & 200 \\
Moscow (Russia) & 22 & 78 & 200 \\
Tartu (Estonia) & 29 & 71 & 200 \\
All centres & 56 & 44 & 1280
\end{tabular}

Table 2 Smoking status by gender and by centre, both years combined

\begin{tabular}{|c|c|c|c|c|c|c|c|c|c|c|}
\hline & \multicolumn{2}{|c|}{$\begin{array}{c}\text { Daily } \\
\text { smokers } \\
(\%)\end{array}$} & \multicolumn{2}{|c|}{$\begin{array}{c}\text { Occasional } \\
\text { smokers } \\
(\%)\end{array}$} & \multicolumn{2}{|c|}{$\begin{array}{c}\text { Ex- } \\
\text { smokers } \\
(\%)\end{array}$} & \multicolumn{2}{|c|}{$\begin{array}{l}\text { Never- } \\
\text { smokers } \\
(\%)\end{array}$} & \multirow{2}{*}{\multicolumn{2}{|c|}{$\begin{array}{c}\text { All students } \\
(n=1280) \\
\stackrel{M}{F} \quad \stackrel{F}{(n=716)(n=564)})\end{array}$}} \\
\hline & $M$ & $F$ & $M$ & $F$ & $M$ & $F$ & $M$ & $F$ & & \\
\hline $\begin{array}{l}\text { AUSTRALIA } \\
\text { JAPAN }\end{array}$ & 2 & 3 & 8 & 4 & 19 & 9 & 71 & 84 & 125 & 68 \\
\hline Hiroshima & 34 & 0 & 11 & 0 & 18 & 7 & 37 & 93 & 187 & 32 \\
\hline Tohoku & 36 & 0 & 13 & 6 & 15 & 6 & 36 & 88 & 169 & 24 \\
\hline USA & 0 & 0 & 0 & 6 & 14 & 29 & 86 & 65 & 44 & 31 \\
\hline $\begin{array}{l}\text { Ex-USSR } \\
\text { St Petersburg (Russia) }\end{array}$ & & 14 & & 21 & & & 22 & 52 & & \\
\hline $\begin{array}{l}\text { St. Petersburg (Russia) } \\
\text { Moscow (Russia) }\end{array}$ & $\begin{array}{l}48 \\
36\end{array}$ & 14 & $\begin{array}{l}14 \\
25\end{array}$ & $\begin{array}{l}21 \\
23\end{array}$ & $\begin{array}{l}16 \\
14\end{array}$ & $\begin{array}{l}13 \\
10\end{array}$ & $\begin{array}{l}22 \\
25\end{array}$ & $\begin{array}{l}52 \\
55\end{array}$ & $\begin{array}{l}87 \\
44\end{array}$ & 113 \\
\hline Tartu (Estonia) & 40 & 11 & 17 & 19 & 19 & 20 & 24 & 50 & $\begin{array}{l}44 \\
59\end{array}$ & 140 \\
\hline
\end{tabular}


It will be seen that ex-smokers comprise $14-19 \%$ of males in different centres, the figures greatly exceeding those for current smokers in Australia and the USA. The figures for female ex-smokers were also substantial and again exceeded those for current smokers in Australia and the USA.

Comparing smoking rates in the first and final years (not shown in table 2), there were higher rates for daily smoking in final-year students in Japan (31\% compared with $26 \%$ in the first year in Hiroshima, $38 \%$ and $26 \%$, respectively, in Tohuku, both sexes combined) but few differences in other centres. (First and final years were, of course, different cohorts.)

\section{Attempts to quit smoking}

Table 3 shows that 33 to $82 \%$ of smokers (daily and occasional combined) had made at least one serious attempt to quit. (This question was not answered by the two US smokers.)

Table 3 "Have you ever made a serious attempt to stop smoking?" Answer: "Yes"

\begin{tabular}{lcc}
\hline & $\begin{array}{c}\text { First } \\
\text { year } \\
(\%)\end{array}$ & $\begin{array}{c}\text { Final } \\
\text { year } \\
(\%)\end{array}$ \\
\hline AUSTRALIA & 50 & 33 \\
JAPAN & 58 & 82 \\
Hiroshima & 65 & 76 \\
Tohoku & $\star$ & $\star$ \\
USA & & \\
Ex-USSR & 42 & 40 \\
St. Petersburg (Russia) & 64 & 37 \\
Moscow (Russia) & 50 & 63 \\
\hline Tartu (Estonia) & & \\
\hline
\end{tabular}

* No information.

Table 4 "What do you think your smoking habits will be five years from now?" Percentage answering "I will certainly not smoke"

\begin{tabular}{lcccc}
\hline & Smokers & $\begin{array}{c}\text { Ex- } \\
\text { smokers }\end{array}$ & $\begin{array}{c}\text { Never- } \\
\text { smokers }\end{array}$ & $p$ \\
\hline AUSTRALIA & 70 & 86 & 92 & $<0.001$ \\
JAPAN & 2 & 44 & 79 & $<0.001$ \\
Hiroshima & 3 & 53 & 75 & $<0.001$ \\
Tohoku & $(50)^{\star}$ & 100 & 98 & $<0.001$ \\
USA & 37 & 86 & 90 & $<0.001$ \\
Ex-USSR & 49 & 64 & 89 & $<0.001$ \\
St. Petersburg (Russia) & 49 & 79 & 89 & $<0.001$ \\
Moscow (Russia) & 45 & & &
\end{tabular}

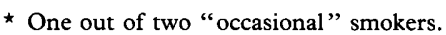

Smoking status five years later

A notable proportion of smokers $(37-70 \%$ ), in all countries except Japan (2-3\%), claimed that they would be non-smokers within five years (table 4). As expected, the percentages were higher for ex- (44-100\%) and never$(75-98 \%)$ smokers.

\section{Personal reasons for not smoking}

The presence of symptoms and/or the protection of their own health were, for smokers and non-smokers alike, the prime reasons for not smoking (table 5). The exemplar role of the doctor was much less prominent, especially in Japanese smokers.

\section{KNOWLEDGE OF THE DANGERS OF TOBACCO} Perception of smoking as "harmful to your health"

Although overall the great majority strongly agreed, the figures were generally lower for smokers (table 6). There was little difference by sex or year of study (not shown in the table).

Knowledge of cigarette smoking as a major cause of specific diseases

In table 7 , the relatively low percentages in Japan and the former USSR listing smoking as a major cause, even of lung cancer, are notable. For most diseases there was an improvement in knowledge between the first and final years, but the ranges between countries were remarkable: e.g., in the final year for chronic bronchitis varying from $35 \%$ in Japan to $84 \%$ in Australia; for emphysema, $12 \%$ in the exUSSR to $75 \%$ in the USA; and for coronary artery disease, $11 \%$ in the ex-USSR to $43 \%$ in Australia. In the USA comparison of first- and final-year replies for chronic bronchitis $(84 \%$ and $64 \%$, respectively) and for coronary artery disease $(45 \%$ and $32 \%$, respectively) seem paradoxical; the explanation may be that the first- and final-year students were from different medical schools and also belonged to different cohorts; there were similar minor "paradoxes" for the former USSR. Moreover, "chronic bronchitis" is now an unfashionable term in the USA, "chronic obstructive airways disease" or similar terminology is more stan-

Table 5 "How do you personally assess the importance of the reasons for not smoking yourself?" Percentage answering: "High" according to smoking status by country

\begin{tabular}{|c|c|c|c|c|c|c|c|c|c|c|c|c|}
\hline & \multicolumn{4}{|c|}{ Smokers } & \multicolumn{4}{|c|}{ Ex-smokers } & \multicolumn{4}{|c|}{ Never-smokers } \\
\hline & Austr & fapan & $U S A$ & USSR & Austr & fapan & $U S A$ & USSR & Austr & Japan & $U S A$ & USSR \\
\hline & & & $\star$ & & & & & & & & & \\
\hline Symptoms & 71 & 53 & $(50)$ & 50 & 38 & 49 & 67 & 47 & 54 & 35 & 57 & 42 \\
\hline To protect your health & 65 & 35 & (50) & 60 & 69 & 53 & 87 & 71 & 88 & 60 & 98 & 74 \\
\hline Example for patients & 53 & 8 & $(100)$ & 30 & 38 & 32 & 60 & 28 & 44 & 23 & 50 & 28 \\
\hline Self-discipline & 29 & 14 & (50) & 42 & 24 & 12 & 40 & 39 & 38 & 4 & 24 & 45 \\
\hline Discomfort & 41 & 18 & (50) & 26 & 28 & 38 & 47 & 20 & 42 & 49 & 28 & 29 \\
\hline Example for children & 35 & 7 & 0 & 51 & 34 & 27 & 40 & 49 & 43 & 27 & 55 & 48 \\
\hline Example for health workers & 24 & 7 & $(50)$ & 10 & 17 & 24 & 40 & 12 & 22 & 13 & 29 & 17 \\
\hline To save money & 29 & 17 & 0 & 12 & 21 & 20 & 7 & 14 & 23 & 15 & 17 & 13 \\
\hline Example for adults & 12 & 3 & $(50)$ & 7 & 3 & 14 & 20 & 8 & 17 & 15 & 29 & 11 \\
\hline Pressure of colleagues & 12 & 4 & 0 & 19 & 3 & 11 & 13 & 13 & 9 & 10 & 2 & 17 \\
\hline
\end{tabular}

« Figures based on only two "occasional" smokers. 
Table 6 "Do you think smoking is harmful to your health?" Percentage answering : "Strongly agree"

\begin{tabular}{lcccc}
\hline & Smokers & $\begin{array}{c}\text { Ex- } \\
\text { smokers }\end{array}$ & $\begin{array}{c}\text { Never- } \\
\text { smokers }\end{array}$ & $p$ \\
\hline AUSTRALIA & 76 & 96 & 93 & $<0.001$ \\
JAPAN & 50 & 68 & 80 & $<0.001$ \\
Hiroshima & 58 & 68 & 80 & $<0.001$ \\
Tohoku & $(100)^{\star}$ & 100 & 100 & NS \\
USA & 72 & 76 & 87 & $<0.001$ \\
Ex-USSR & 72 & 82 & 88 & $<0.001$ \\
St. Petersburg (Russia) & 73 & 87 & 89 & $<0.001$ \\
Moscow (Russia) & & & & \\
Tartu (Estonia) & & & \\
\hline
\end{tabular}

* Two out of two smokers.

$\mathrm{NS}=$ non-significant dard; this could have led to some confusion among the US students.

Figures for peripheral vascular disease (PVD), bladder cancer and neonatal mortality were very low in all countries (except for PVD in Australia).

\section{ATTITUDE TOWARDS PATIENTS' SMOKING}

Students were asked "In the following situations would you, as a future doctor, advise patients against smoking?" Three situations were proposed, summarised below. Percentages of

Table 7 For each of the diseases listed below, please indicate whether you think that cigarette smoking is a major cause, a contributing cause, is associated with, or has no association with the disease or condition. Percentage answering : "Major cause," by country and year

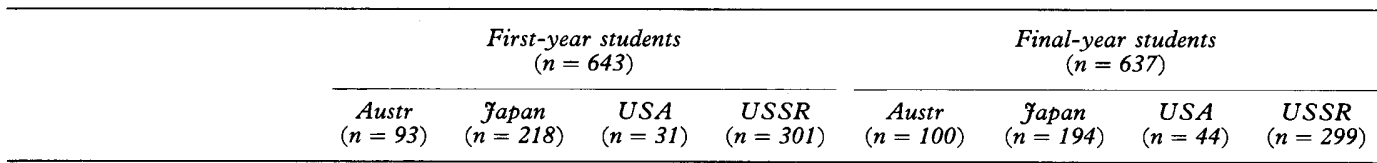

Lung cancer

Chronic bronchitis

Oral cancer

Laryngeal cancer

Pulmonary emphysema

Coronary artery disease

Leukoplakia

Peripheral vascular disease

Any soft tissue lesion

Neo-natal death

Bladder cancer

$\begin{array}{rr}80 & 53 \\ 48 & 24 \\ 27 & 16 \\ 32 & 18 \\ 35 & 17 \\ 30 & 8 \\ 18 & 3 \\ 13 & 9 \\ 16 & 0 \\ 15 & 2 \\ 3 & \end{array}$

$\begin{array}{rr}53 & 100 \\ 24 & 84 \\ 16 & 74 \\ 18 & 84 \\ 17 & 90 \\ 8 & 45 \\ 3 & 29 \\ 9 & 13 \\ 0 & 6 \\ 2 & 3 \\ 1 & 3\end{array}$

$\begin{array}{rr}100 & 67 \\ 84 & 53 \\ 74 & 40 \\ 84 & 32 \\ 90 & 18 \\ 45 & 11 \\ 29 & 11 \\ 13 & 10 \\ 6 & 10 \\ 3 & 8 \\ 3 & 3\end{array}$

$\begin{array}{rr}67 & 91 \\ 53 & 84 \\ 40 & 39 \\ 32 & 44 \\ 18 & 67 \\ 11 & 43 \\ 11 & 26 \\ 10 & 45 \\ 10 & 6 \\ 8 & 3 \\ 3 & 2\end{array}$

$\begin{array}{rr}91 & 53 \\ 84 & 35 \\ 39 & 25 \\ 44 & 27 \\ 67 & 20 \\ 43 & 19 \\ 26 & 10 \\ 45 & 9 \\ 6 & 0 \\ 3 & 4 \\ 2 & \end{array}$

$\begin{array}{rr}53 & 93 \\ 35 & 64 \\ 25 & 45 \\ 27 & 41 \\ 20 & 75 \\ 19 & 32 \\ 10 & 32 \\ 9 & 9 \\ 0 & 18 \\ 4 & 7 \\ 3 & 5\end{array}$

$\begin{array}{rr}93 & 51 \\ 64 & 67 \\ 45 & 32 \\ 41 & 24 \\ 75 & 12 \\ 32 & 11 \\ 32 & 12 \\ 9 & 12 \\ 18 & 6 \\ 7 & 6 \\ 5 & 2\end{array}$

Table 8 Percentage of final-year students answering "often" to the question "In these three situations would you, as a future doctor, advise patients against smoking?" (For definition of situations, see text)

\begin{tabular}{lccc}
\hline & $\begin{array}{c}\text { Situation } 1 \\
(\%)\end{array}$ & $\begin{array}{c}\text { Situation } 2 \\
(\%)\end{array}$ & $\begin{array}{c}\text { Situation } 3 \\
(\%)\end{array}$ \\
\hline AUSTRALIA & 96 & 93 & 57 \\
JAPAN & & 57 & 2 \\
Hiroshima & 89 & 77 & 9 \\
Tohoku & 89 & 61 \\
USA & $(100$ & 100 & 43 \\
Ex-USSR & 88 & 82 & 53 \\
St. Petersburg (Russia) & 94 & 87 & 19 \\
Moscow (Russia) & 82 & 69 & 35 \\
Tartu (Estonia) & 91 & 81 & \\
All centres & & &
\end{tabular}

final-year students answering "often" are given in table 8.

Situation 1: "In a patient with a smokingrelated condition" (recognised by the student). In all centres a high proportion of final-year students would advise against smoking.

Situation 2: "When the patient himself raises the question about smoking." The results were similar to those for Situation 1.

Situation 3: "When a patient is a smoker who has no symptoms or diagnosis of a smokingrelated disease and does not himself raise the question of smoking." There were large dif-

Table 9 "Indicate the extent to which you agree or disagree with each of the statements" Percentage answering: "Strongly agree" according to smoking status, by country (\%), in final-year students

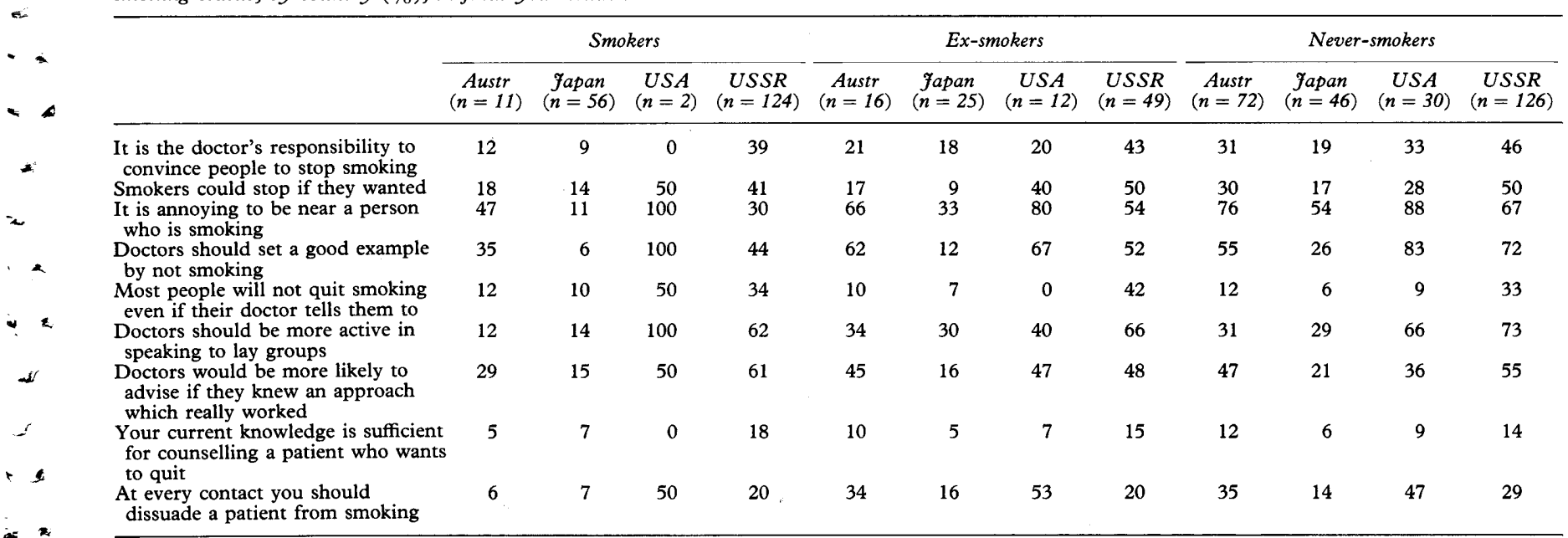


Table 10 "A number of opinions have been expressed about how to reduce smoking through legislative action. Would you agree or disagree with the following opinions?" Percentage answering: "Strongly agree" according to smoking status by country, in final-year students

\begin{tabular}{|c|c|c|c|c|c|c|c|c|c|c|c|c|}
\hline & \multicolumn{4}{|c|}{ Smokers } & \multicolumn{4}{|c|}{ Ex-smokers } & \multicolumn{4}{|c|}{ Never-smokers } \\
\hline & $\begin{array}{c}\text { Austr } \\
(n=11)\end{array}$ & $\begin{array}{c}\text { Japan } \\
(n=56)\end{array}$ & $\begin{array}{c}U S A \\
(n=2)\end{array}$ & $\begin{array}{c}U S S R \\
(n=124)\end{array}$ & $\begin{array}{c}\text { Austr } \\
(n=16)\end{array}$ & $\begin{array}{c}\text { fapan } \\
(n=25)\end{array}$ & $\begin{array}{c}U S A \\
(n=12)\end{array}$ & $\begin{array}{c}\text { USSR } \\
(n=49)\end{array}$ & $\underset{(n=72)}{\text { Austr }}$ & $\begin{array}{c}\text { fapan } \\
(n=46)\end{array}$ & $\begin{array}{c}U S A \\
(n=30)\end{array}$ & $\begin{array}{c}U S S R \\
(n=126)\end{array}$ \\
\hline Health warning on cigarette package & 71 & 10 & 100 & 35 & 90 & 28 & 100 & 48 & 88 & 26 & 93 & 45 \\
\hline Complete ban on advertising & 41 & 4 & 50 & 50 & 48 & 8 & 53 & 65 & 59 & 7 & 67 & 64 \\
\hline Tobacco restricted in public places & 59 & 12 & 100 & 50 & 90 & 48 & 100 & 83 & 79 & 53 & 91 & 86 \\
\hline Price of tobacco increased & 12 & 4 & 50 & 17 & 34 & 16 & 40 & 35 & 34 & 12 & 43 & 44 \\
\hline $\begin{array}{l}\text { Sale of tobacco to children } \\
\text { prohibited }\end{array}$ & 71 & 30 & 50 & 75 & 79 & 41 & 87 & 77 & 75 & 45 & 84 & 79 \\
\hline Smoking in hospital restricted & 76 & 36 & 100 & 83 & 93 & 63 & 100 & 87 & 78 & 64 & 95 & 87 \\
\hline $\begin{array}{l}\text { Health professionals should be } \\
\text { trained to counsel patients on } \\
\text { quitting }\end{array}$ & 65 & 7 & 100 & 77 & 72 & 27 & 87 & 79 & 73 & 19 & 83 & 81 \\
\hline
\end{tabular}

ferences between countries, ranging from only $2 \%$ replying "often" in Hiroshima, to $61 \%$ in the USA. For each centre, and for each situation, there was little difference between the figures for first-year students (not shown) and for final-year students. The overall percentages for smokers (not shown in the table) were similar to those for ex-and never-smokers for Situation 1 but lower for Situation 2 (68\% compared to $82 \%$ and $81 \%$, respectively) and for Situation $3(26 \%$ compared to $35 \%$ and $36 \%$ ).

\section{ATTITUDES TOWARDS ANTI-SMOKING CAMPAIGNS}

In response to the question "What is the role of the doctor in anti-smoking campaigns?", the student was asked to "Indicate the extent to which you agree or disagree with each of the following statements." Table 9 shows considerable differences between countries. On the whole US, USSR, and Australian students seem more conscious than Japanese students of the importance of their exemplar role and their responsibility to advise patients to stop smoking. As would be expected, smokers were less aware of these responsibilities. In all countries very few students felt their knowledge was sufficient to counsel patients on quitting.

ATTITUDES TOWARDS LAWS AND REGULATIONS FOR CONTROLLING THE TOBACCO PROBLEM Students were asked " $A$ number of opinions have been expressed about how to reduce smoking through legislative actions. Would you agree or disagree with the following opinions?" Table 10 gives the percentages replying "strongly agree" by country and smoking status. Australian and US students were most, and Japanese students least, supportive of antismoking legislation. Overall there was least support for a price increase (tax) on tobacco, though this has been shown to be one of the most effective ways of decreasing consumption. ${ }^{6}$

\section{Discussion}

This report is the fourth in a series giving the results of the IUATLD's global survey of the behaviour, knowledge and attitudes of medical students towards tobacco. The global survey has covered more than 5000 students in 54 centres from 42 countries. The present report concerned four major industrialised countries ; the survey was done before the dissolution of the USSR. The USSR questionnaires had not been received in time for the European report on 14 countries, prepared for the WHO European Region's intergovernmental conference in Madrid in $1988 .^{2}$ We also decided that highly industrialised Japan was more appropriately analysed with other large industrialised countries than with the less developed Asian countries. ${ }^{3}$

Although there were some problems with the returns from the USA, in so far as we received information only for first-year students from one school and from the final year from another, we thought it useful to include the results for comparison with Japan and the former USSR, where the climate of medical and public opinion about tobacco is much less advanced. Although the USA data must be treated with reserve given the small sample size, they are consonant with general knowledge about the attitudes in that country's medical schools. In view of the high response rates we believe our results probably give a reasonable measure of the relevant behaviour, knowledge and attitudes of medical students in these countries.

As the four countries (now five, with the independence of Estonia) surveyed in this report differ in many respects, including, as it has turned out, the results of the survey, it has seemed to us more helpful to present figures as comparisons between countries rather than to bulk them and give overall means. Although to some extent comparable in industrial development, with some reservations regarding the present economic problems in former USSR, the countries are at different stages in their "smoking culture". Australia and the USA have had very long histories of tobacco use but have now for many years been subject to intensive anti-smoking campaigns by governmental and non-governmental organisations.

In consequence of the differing stages of the anti-smoking campaigns in these countries, there are major differences in smoking prevalence. Relevant figures for adult populations are: Australian males $-40 \%$ in 1980 and $30 \%$ in 1989 , females $-31 \%$ and $27 \%$, respectively; USA males $-38 \%$ in 1979 and $32 \%$ in 1987 , females $-29 \%$ and $27 \%$, respectively. In contrast, Japan still has very high smoking rates in males $(78 \%$ in $1970,61 \%$ in 1989) though 
much lower rates in females $(16 \%$ and $13 \%$, respectively). Anti-smoking activity is relatively recent and has so far had little governmental support. In former USSR anti-smoking campaigns are also relatively recent.

Smoking rates in medical students (table 2) in general reflected these national differences but were substantially below the rates for the general population in Australia, the USA, and Japan. We have found the same trends in our results from other countries. In the USSR we have only been able to obtain general population data from Moscow; there the male medical student prevalence of daily smoking was somewhat lower, $36 \%$ compared to $50 \%$ in the general population, but the rate in females was similar; $12 \%$ for students, $10 \%$ for the general population.

As in our results from other countries, notable proportions of smokers had made a serious attempt to stop. With the important exception of Japan, $37-70 \%$ of smokers thought they would no longer be smoking in 5 years' time. Though this confidence may for some students prove illusory, at least it indicates encouraging motivation.

The differences in attitudes and knowledge found in this survey reflect widespread international differences ${ }^{7,8,9}$ and remain a challenge to medical educators, even to some extent in the USA and Australia. Though most students appreciated that smoking was harmful to health, the widespread ignorance of smoking as a major cause of cardiovascular disease, emphysema, laryngeal and bladder cancer, and neonatal mortality, is particularly regrettable. Among many students in Japan and the former USSR, the ignorance extended to lung cancer. Major efforts should be made to correct it. A high proportion of students did not yet appreciate their responsibility to counsel all smoking patients to quit and they apparently had little training in how to do so. There was variable knowledge of, and support for, legislative action and particular ignorance of the value of tobacco taxation as a preventive measure. ${ }^{6}$

One of the aims of the survey was to stimulate the interest of students and their teachers. In Japan, our questionnaire was used to conduct surveys in a number of other medical schools. In the former USSR we were asked for an additional 5000 copies of the questionnaire for the same purpose. We hope that this interest will lead to an improvement of students' knowledge of tobacco as a cause of specific diseases and an improvement in knowledge and attitudes regarding preventive action. We are considering a selective 5-year follow-up to determine further progress.

We are most grateful to Prof. Ann Woolcock (Australia), Prof T Mori (Japan), Prof A G Khomenko and Dr V V Erokhin (former USSR), Dr T Petty (Denver, Colorado, USA) and Dr (former USSR), Dr T Petty (Denver, Colorado, USA) and Dr J Murray (San Francisco, USA) for their helpful local co-
ordination of the survey. We thank Ms Catherine Royce of ordination of the survey. We thank Ms Catherine Royce of
Action on Smoking and Health (ASH) UK for providing the Action on Smoking and Health (ASH) UK for providing the figures on smoking prevalence in the general populations; and
Ms M A Audibert and Mrs E A Pretty for secretarial assistance. Ms M A Audibert and Mrs E A Pretty for secretarial assistance. We acknowledge with gratitude the provision of facilities from the University of Bordeaux II, France; the collaboration of the Unité INSERM 330 and the Laboratoire d'Informatique et de BioStatistique, University of Bordeaux II (Prof. R Salamon); and the technical assistance of Mrs S Redon, Assistante Ingenieur of INSERM, Bordeaux, France. We are most grateful for financial grants from the WHO, Geneva, the International Union against Tuberculosis and Lung Disease, the Danish National Association against Tuberculosis and Lung Disease, and the Chest Heart and Stroke Association, Scotland.

1 Fréour P, Tessier JF, Crofton J. Étude pilote cooperative de l'UICTMR. Les étudiants en medecine et le tabac. Santé Publique 1988; 2: 21-30.

2 Tessier JF, Fréour P, Crofton J, Kombou L. Smoking habits, and attitudes of medical students towards smoking and anti-smoking campaigns in fourteen European countries. Eur ₹ Epidemiol $1989 ; 5$ (3): 311-9.

3 Tessier JF, Fréour P, Belougne D, Crofton J. Smoking habits, and attitudes of medical students towards smoking and anti-smoking campaigns in nine Asian countries. Int f Epidemiol 1992; 21 (2): 298-302.

4 Tessier JF, Fréour PP, Neijari C, Belougne D, Crofton JW. Smoking behaviour and attitudes of medical students towards smoking and anti-smoking campaigns: a survey towards smoking and anti-smoking campaigns: a survey Control 1992; 1 : 95-101.

5 World Health Organisation. Directives pour la conduite d'enquêtes sur le tabagisme parmi les professionels de la santé. WHO/SMO/84/1.

6 Townsend J. Tobacco price and the smoking epidemic. Smokefree Europe: 9. Copenhagen: WHO Regional Office for Europe/Commission of the European Communities, 1988.

7 Fréour P. La mission éducative du médecin dans la défense de la santé. Bull Acad Natl Med 1980;164 (7): 644-649.

Fréour P. Le tabagisme d'aujourdhui et les médecins. Bull Acad Natl Med 1988; 172 (3): 347-353.

9 Elkind AK. Smoking. How medical students see the doctor's role. Public Health Lond 1983; 97 : 38-45. 